\title{
3: 42825980-42883779
}

National Cancer Institute

\section{Source}

National Cancer Institute. 3:42825980-42883779. NCI Thesaurus. Code C41854.

Physical location of CCBP2_Gene 